\title{
Estimation of Gas-Phase Acidities of Deoxyribonucleosides: An Experimental and Theoretical Study
}

\author{
Sangeeta Kumari, ${ }^{\text {a }}$ Chebrolu Lavanya Devi, ${ }^{\text {b }}$ Sripadi Prabhakar, \\ Kotamarthi Bhanuprakash, ${ }^{\mathrm{b}}$ and Mariappanadar Vairamani ${ }^{\mathrm{a}}$ \\ ${ }^{a}$ National Center for Mass Spectrometry, Indian Institute of Chemical Technology, Hyderabad 500 607, India \\ ${ }^{b}$ Inorganic Chemistry Division, Indian Institute of Chemical Technology, Hyderabad 500 607, India
}

We determined the gas-phase acidities $\left(\Delta \mathrm{H}_{\text {acid }}\right)$ of four deoxyribonucleosides, i.e., $2^{\prime}$ deoxyadenosine (dA), 2'-deoxyguanosine (dG), 2'-deoxycytidine (dC), and 2'-deoxythymidine (dT) by applying the extended kinetic method. The negatively charged proton-bound hetero-dimeric anions, $[\mathrm{A}-\mathrm{H}-\mathrm{B}]^{-}$of the deoxyribonucleosides (A) and reference compounds (B) were generated under electrospray ionization conditions. Collision-induced dissociation spectra of $[\mathrm{A}-\mathrm{H}-\mathrm{B}]^{-}$were recorded at four different collision energies using a triple quadrupole mass spectrometer. The abundance ratios of the individual monomeric product ions were used to determine the $\Delta \mathrm{H}_{\text {acid }}$ of the deoxyribonucleosides. The obtained $\Delta \mathrm{H}_{\text {acid }}$ value follows the order $\mathrm{dA}>\mathrm{dC}>\mathrm{dT}>\mathrm{dG}$. The $\Delta \mathrm{G}_{\text {acid }}(298 \mathrm{~K})$ values were determined by using $\Delta \mathrm{G}_{\text {acid }}=\Delta \mathrm{H}_{\text {acid }}$ $-\mathrm{T} \Delta \mathrm{S}_{\text {acid }}$ where the $\Delta \mathrm{H}_{\text {acid }}$ and $\Delta \mathrm{S}_{\text {acid }}$ values were determined directly from the kinetic method plots. The $\Delta \mathrm{H}_{\text {acid }}$ values were also predicted for the deoxyribonucleosides at the B3LYP/6$311+G^{* *} / /$ B3LYP $/ 6-311 G^{* *}$ level of theory. The acidity trend obtained from the computational investigation shows good agreement with that obtained experimentally by the extended kinetic method. Theoretical calculations provided the most preferred deprotonation site as $\mathrm{C}^{\prime}-\mathrm{OH}$ from sugar moiety in case of $\mathrm{dA}$, and as $-\mathrm{NH}_{2}$ (dC and $\mathrm{dG}$ ) or $-\mathrm{NH}-(\mathrm{dT})$ from nitrogenous base moiety in the case of other deoxyribonucleosides. (J Am Soc Mass Spectrom 2010, 21, 136-143) (c) 2010 American Society for Mass Spectrometry

$\mathrm{D}$ eoxyribonucleosides are fundamental building blocks of DNA and play a major role in therapeutic applications as antiviral agents [1]. The determination of thermochemical properties of these molecules in the gas phase could be of importance for biological reasons because biological environment can be relatively nonpolar in nature. Moreover, the gasphase studies explore the reactivity of molecules and ions without solvent effects. To date, mass spectral studies have been focused towards analysis and structural characterization of deoxyribonucleosides [2-10]. While thermochemical properties of individual nucleobases have been well studied experimentally in the gas phase, the studies on nucleosides are limited [11-16].

Xia et al. [11] performed extensive calculations on proton affinities (PAs) of nucleosides by the density functional approach. The PA of the four deoxyribonucleosides, i.e., 2'-deoxyadenosine (dA), 2'-deoxyguanosine (dG), 2'-deoxycytidine $(\mathrm{dC})$, and 2 '-deoxythymidine (dT) were reported to be in the order of $\mathrm{dG}>\mathrm{dC}>\mathrm{dA}>\mathrm{dT}$, and this order is similar to the PA order of the free bases $(G>C>$

Address reprint requests to Dr. M. Vairamani, National Center for Mass Spectrometry, Indian Institute of Chemical Technology, Hyderabad 500 607, India. E-mail: mvairamani@hotmail.com
A $>$ T). They concluded the protonation features of deoxyribonucleosides were less changed compared with the corresponding free bases. Donna et al. [12] determined the PA of $\mathrm{dA}$ and demonstrated the effective use of the kinetic method for the thermochemical measurement of multifunctional molecules like nucleosides and nucleobases. Besides the wide array of proton affinity studies on deoxyribonucleosides [13-16], there have been no experimental or theoretical reports on the gas-phase acidities $\left(\Delta \mathrm{H}_{\text {acid }}\right)$ of deoxyribonucleosides. In this study, we report the first determination of $\Delta \mathrm{H}_{\text {acid }}$ of $\mathrm{dA}, \mathrm{dG}, \mathrm{dC}$, and $\mathrm{dT}$ through application of the extended kinetic method. We have also calculated the $\Delta \mathrm{H}_{\text {acid }}$ values of the deoxyribonucleosides by applying theoretical calculations to investigate the influence of glycosyl group on the $\Delta \mathrm{H}_{\text {acid }}$ of deoxyribonucleosides.

\section{Computational}

All calculations were carried out using the Gaussian 03w software [17]. Most stable structures of deoxyribonucleosides were taken from the earlier reports [18]. Geometrical optimizations and the vibrational frequencies of the neutral and deprotonated forms of all deoxyribonucleosides were carried out with B3LYP 
method using 6-311G(d,p) basis set. Total electronic energies were obtained by single point calculations at the higher basis set $6-311+\mathrm{G}(\mathrm{d}, \mathrm{p})$. The zero-point vibrational energies and thermal corrections from the frequency analysis at the B3LYP/6-311G(d,p) level were considered to provide enthalpies at $298.15 \mathrm{~K}$.

The gas-phase acidities were calculated using the following equation by directly taking enthalpy of proton as $\frac{5}{2} R T$ [19]

$$
\mathrm{HA} \rightarrow \mathrm{H}^{+}+\mathrm{A}^{-}
$$

$$
\Delta_{\text {acid }} \mathrm{H}_{298}^{0}=\mathrm{H}_{298}^{0}\left(\mathrm{~A}^{-}\right)-\mathrm{H}_{298}^{0}(\mathrm{AH})+\frac{5}{2} R \mathrm{~T}
$$

\section{Experimental}

\section{Materials}

All the chemicals were procured from Aldrich (Steinheim, Germany) and were used without further purification. Stock $(1 \mathrm{mM})$ solutions of the deoxyribonucleosides and the references (listed in Table 1) were prepared in basic $\left(1 \% \mathrm{NH}_{4} \mathrm{OH}\right)$ methanol:water solution (50:50, vol:vol). The stock solutions of the deoxyribonucleosides and the references were mixed in appropriate volumes and diluted with methanol to achieve a final concentration of $50 \mu \mathrm{M}$ each. Sample solutions were introduced into the source of the mass spectrometer by using inbuilt syringe pump at a flow rate of 5 $\mu \mathrm{L} / \mathrm{min}$.

\section{Mass Spectrometry}

Experiments were performed using a Quattro micro LC triple-quadrupole mass spectrometer (Waters, Manchester, UK) interfaced to an ESI source; data acquisition was done under the control of MassLynx software (version 4.1). Typical settings were capillary voltage -2.5 to -3 $\mathrm{kV}$, cone voltage $10-15 \mathrm{~V}$, source temperature $100^{\circ} \mathrm{C}$, desolvation temperature $100{ }^{\circ} \mathrm{C}$. Nitrogen was used as desolvation and nebulization gas. The CID spectra were obtained by selecting the proton-bound hetero-dimeric anions with the first quadrupole (MS1), fragmenting them in the collision cell at four different collision energies $(5,8,10$, and $12 \mathrm{eV})$ in the laboratory frame, and recording the resulted fragment ions by scanning the second quadrupole $\left(\mathrm{MS}^{2}\right)$. Argon was used as the collision gas at a pressure of $5.0 \times 10^{-4}$ mbar. Under the experimental conditions the number of collisions with the target may be 3-10 [20].

\section{The Kinetic Method}

The kinetic method developed by Cooks and coworkers $[21,22]$ is widely applied in gas-phase thermochemical measurements. In this method, proton-bound heterodimeric anions between molecule of interest (A) and a set of reference acids (B) are generated. These ions are subjected to collision induced dissociation (CID), which results into individual monomeric anions through competitive dissociations (eq 3 ).

$$
[\mathrm{A}]+[\mathrm{B}-\mathrm{H}]^{-} \stackrel{\mathrm{k}_{2}}{\leftarrow}[\mathrm{A}-\mathrm{H}-\mathrm{B}]^{-} \stackrel{\mathrm{k}_{1}}{\rightarrow}[\mathrm{A}-\mathrm{H}]^{-}+[\mathrm{B}]
$$

The abundance ratio $[\mathrm{A}-\mathrm{H}]^{-} /[\mathrm{B}-\mathrm{H}]^{-}$reflects the rate constant ratio $k_{1} / k_{2}$, where $k_{1}$ and $k_{2}$ are the rate constants for the competitive dissociations of the dimeric anion to produce $[\mathrm{A}-\mathrm{H}]^{-}$and $[\mathrm{B}-\mathrm{H}]^{-}$, respectively. The ratio of rate constants can be derived using unimolecular reaction theory (eq 4) [21, 22].

$$
\begin{gathered}
\ln \left[\mathrm{A}-\mathrm{H}^{-} / \mathrm{B}-\mathrm{H}^{-}\right]=\Delta(\Delta \mathrm{S}) / \mathrm{R}+\Delta \mathrm{H}_{\mathrm{acid}}(\mathrm{A}) / \mathrm{RT}_{\mathrm{eff}} \\
-\Delta \mathrm{H}_{\text {acid }}(\mathrm{B}) / \mathrm{RT}_{\mathrm{eff}}
\end{gathered}
$$

\begin{tabular}{|c|c|c|c|c|}
\hline Analyte & Reference & $\Delta \mathrm{G}(\mathrm{kJ} / \mathrm{mol})$ & $\Delta \mathrm{H}(\mathrm{kJ} / \mathrm{mol})$ & $\Delta \mathrm{S}(\mathrm{J} / \mathrm{mol})$ \\
\hline \multirow[t]{4}{*}{ 2'-Deoxy-guanosine } & 3-Nitro-benzoic acid & $1347 \pm 8.4$ & $1377 \pm 8.8$ & 100.6 \\
\hline & 4-Hydroxy-benzaldehyde & $1364 \pm 8.4$ & $1393 \pm 8.8$ & 97.3 \\
\hline & 3-Nitrophenol & $1370 \pm 8.4$ & $1399 \pm 8.8$ & 97.3 \\
\hline & 4-Hydroxy-acetophenone & $1375 \pm 8.4$ & $1404 \pm 8.8$ & 97.3 \\
\hline \multirow[t]{4}{*}{ 2'-Deoxy-thymidine } & 3-Hydroxy-benzoic acid & $1387 \pm 8.4$ & $1417 \pm 8.8$ & 100.6 \\
\hline & Benzoic acid & $1394 \pm 8.4$ & $1423 \pm 9.2$ & 97.3 \\
\hline & 4-methyl-benzoic acid & $1396 \pm 8.4$ & $1425 \pm 8.8$ & 97.3 \\
\hline & 3-Amino-benzoic acid & $1400 \pm 8.4$ & $1429 \pm 8.8$ & 97.3 \\
\hline \multirow[t]{4}{*}{ 2'-Deoxy-cytidine } & 3-Amino-benzoic acid & $1400 \pm 8.4$ & $1429 \pm 8.8$ & 97.3 \\
\hline & 3-Hydroxy-acetophenone & $1404 \pm 8.4$ & $1433 \pm 8.8$ & 97.3 \\
\hline & 4-Chloro-phenol & $1407 \pm 8.4$ & $1436 \pm 8.8$ & 97.3 \\
\hline & 2-tert-Butyl-phenol & $1415 \pm 8.4$ & $1447 \pm 9.2$ & 107.3 \\
\hline \multirow[t]{4}{*}{ 2'-Deoxy-adenosine } & 2-tert-Butyl-phenol & $1415 \pm 8.4$ & $1447 \pm 9.2$ & 107.3 \\
\hline & Resorcinol & $1422 \pm 8.4$ & $1451 \pm 8.8$ & 97.3 \\
\hline & 3-Cresol & $1434 \pm 8.4$ & $1463 \pm 8.8$ & 97.3 \\
\hline & Hydroquinone & $1436 \pm 8.4$ & $1466 \pm 8.8$ & 100.6 \\
\hline
\end{tabular}

Table 1. Reference compounds used and their $\Delta \mathrm{G}, \Delta \mathrm{H}$ and $\Delta \mathrm{S}$ values ${ }^{\mathrm{a}}$

${ }^{\mathrm{a}} \Delta \mathrm{G}$ and $\Delta \mathrm{H}$ obtained from the NIST Chemistry Web book [27] and $\Delta \mathrm{S}$ calculated from the equation $\Delta \mathrm{G}=\Delta \mathrm{H}-\mathrm{T} \Delta \mathrm{S}$ at $298 \mathrm{~K}$. 
With the first assumption that no reverse energy barrier exists for the two dissociation pathways (eq 3), and equal detection efficiencies for the two ions, the ratio $\left[\mathrm{A}-\mathrm{H}^{-} / \mathrm{B}-\mathrm{H}^{-}\right]$is equal to the rate constant ratio $\left(\mathrm{k}_{1}\right.$ $\left./ \mathrm{k}_{2}\right)$. With the second assumption that both analyte and the reference bases are structurally similar and $\Delta(\Delta S) \approx$ 0 , the eq 4 can be rewritten as eq 5 .

$$
\begin{aligned}
& \ln \left(\mathrm{A}-\mathrm{H}^{-} / \mathrm{B}-\mathrm{H}^{-}\right) \\
& \quad=\Delta \mathrm{H}_{\mathrm{acid}}(\mathrm{A}) / \mathrm{RT}_{\mathrm{eff}}-\Delta \mathrm{H}_{\mathrm{acid}}(\mathrm{B}) / \mathrm{RT}_{\mathrm{eff}}
\end{aligned}
$$

This simple form of the kinetic method is applicable to most of the compounds assuming (1) the activation energies for reverse reactions are negligible, and (2i) entropy changes for the two fragmentation channels are the same. The first assumption is applied to weakly bound singly charged cluster ions, while the second assumption is valid only for the species without internal hydrogen bonding [21, 22].

If the reference compounds are structurally different from the analyte of interest, the eq 5 yields errors in the $\Delta \mathrm{H}_{\text {acid }}$ values due to different entropic contributions between the two dissociation channels. In such cases, the extended kinetic method is used [23-30], where experiments are performed at different collision energies to measure variations in effective temperature $T_{\text {eff }}$. The plots of $\ln \left[\mathrm{A}-\mathrm{H}^{-} / \mathrm{B}-\mathrm{H}^{-}\right]$measured at different collision energy versus the gas-phase acidities of the reference acids give a set of slopes and intercepts. When these slopes and intercepts are plotted against each other, it separates the entropy and enthalpy terms. The new regression line thus obtained gives $\Delta \mathrm{H}_{\text {acid }}$ from the slope and $\Delta(\Delta S)$ from the intercept in accord with the relation shown in eq 6 . The term in the square bracket represents an apparent $\Delta \mathrm{G}_{\text {acid }} / \mathrm{RT}_{\text {eff }}$ of the unknown acid $A$, where $\Delta G_{\text {acid }}$ defined by eq 7 .

$$
\begin{aligned}
& \ln \frac{\mathrm{k}_{1}}{\mathrm{k}_{2}}=\left[\frac{\Delta \mathrm{H}_{\text {acid }}(\mathrm{A})}{\mathrm{RT}_{\text {eff }}}-\frac{\Delta(\Delta \mathrm{S})}{\mathrm{R}}\right]-\frac{\Delta \mathrm{H}_{\text {acid }}(\mathrm{B})}{\mathrm{RT}_{\text {eff }}} \\
& \Delta \mathrm{G}^{\mathrm{app}}(\mathrm{A})=\Delta \mathrm{H}_{\text {acid }}(\mathrm{A})-\mathrm{T}_{\text {eff }} \Delta(\Delta \mathrm{S})
\end{aligned}
$$

The term $\Delta(\Delta S)$ represents the difference in the entropy change for the two dissociation channels of the dimeric anion. Nevertheless, the new regression lines obtained from such data show almost perfect correlation coefficients that may lead to underestimated experimental uncertainties. To decrease the severity of this problem, Armentrout [30] suggested plotting $\ln \left[\mathrm{A}-\mathrm{H}^{-} / \mathrm{B}-\mathrm{H}^{-}\right]$ against $\left[\Delta \mathrm{H}_{\text {acid }}(\mathrm{B})-\Delta \mathrm{H}_{\text {acid }}\left(\mathrm{B}_{\text {avg }}\right)\right]$, where $\Delta \mathrm{H}_{\text {acid }}\left(\mathrm{B}_{\text {avg }}\right)$ is the average gas-phase acidity value of all the references used for the particular measurement (statistical approach). The slope and intercept of this plot give $\left[1 / \mathrm{RT}_{\text {eff }}\right]$ and $\left\{-\left[\Delta \mathrm{H}_{\text {acid }}(\mathrm{A})-\Delta \mathrm{H}_{\text {acid }}(\mathrm{B})_{\mathrm{avg}}\right] / \mathrm{RT}_{\mathrm{eff}}-(\Delta \mathrm{S}) / \mathrm{R}\right\}$, respectively. The plot of negative of intercepts against corresponding slopes, give $\left[\Delta \mathrm{H}_{\text {acid }}(\mathrm{A})-\Delta \mathrm{H}_{\text {acid }}(\mathrm{B})_{\text {avg }}\right]$ from the slope and $-\Delta(\Delta S) / \mathrm{R}$ from the intercept. This method is used in cases where reference compounds are structurally different from the analyte of interest.

\section{Results and Discussion}

The structures of the studied deoxyribonucleosides $(\mathrm{dA}, \mathrm{dG}, \mathrm{dC}$, and $\mathrm{dT})$ are shown in Scheme 1. CID experiments were carried out on $[\mathrm{M}-\mathrm{H}-\mathrm{X}]^{-}$, where $\left(\mathrm{X}^{-}=\mathrm{Br}^{-}, \mathrm{I}^{-}, \mathrm{F}^{-}, \mathrm{Cl}^{-}, \mathrm{CH}_{3} \mathrm{COO}^{-}, \mathrm{CF}_{3} \mathrm{COO}^{-}, \mathrm{HCOO}^{-}\right)$ to evaluate the approximate $\Delta \mathrm{H}_{\text {acid }}$ values and the relative acidities of the deoxyribonucleosides. When $\mathrm{X}=\mathrm{F}^{-}$and $\mathrm{CH}_{3} \mathrm{COO}^{-}$, the spectra showed only [M $\mathrm{H}]^{-}$ions and this suggests higher $\Delta \mathrm{H}_{\text {acid }}$ values for the anions than that for the deoxyribonucleosides. In the case of $\mathrm{Br}^{-}, \mathrm{I}^{-}$, and $\mathrm{CF}_{3} \mathrm{COO}^{-}$, the spectra exclusively yielded $\mathrm{X}^{-}$ion confirming lesser $\Delta \mathrm{H}_{\text {acid }}$ for these anions than that for the deoxyribonucleosides. In the case of $\mathrm{Cl}^{-}$and $\mathrm{HCOO}^{-}$, the spectra showed both $\mathrm{X}^{-}$and $[\mathrm{M}-$ $\mathrm{H}^{-}$anions, and this shows that the $\Delta \mathrm{H}_{\text {acid }}$ values of the deoxyribonucleosides studied are closer to that of $\mathrm{Cl}^{-}$ $(\Delta \mathrm{H}=1395 \mathrm{~kJ} / \mathrm{mol})$ and $\mathrm{HCOO}^{-}$anion $(\Delta \mathrm{H}=1444$ $\mathrm{kJ} / \mathrm{mol}$ ) [31]. The CID spectra obtained with $\mathrm{HCOO}^{-}$ (Figure 1) provides the relative acidity order for the deoxyribonucleosides as $\mathrm{dA}>\mathrm{dC}>\mathrm{dT}>\mathrm{dG}$.

With a view to determining the $\Delta \mathrm{H}_{\text {acid }}$ values of deoxyribonucleosides (A) by applying the kinetic method, derivatives of aromatic compounds (mostly benzoic acid and phenol derivatives) were selected as the references (B). Four references were used for each deoxyribonucleoside, and their $\Delta \mathrm{G}_{\text {acid }}, \Delta \mathrm{S}_{\mathrm{acid}}$, and $\Delta \mathrm{H}_{\text {acid }}$ values are listed in Table 1 [32]. The CID spectra of the proton-bound hetero-dimeric anions [A $-\mathrm{H}-$ $\mathrm{B}]^{-}$were recorded at four collision energies: 5, 8, 10, and $12 \mathrm{eV}$. The spectra exclusively yielded two individual monomeric anions, $[\mathrm{A}-\mathrm{H}]^{-}$and $[\mathrm{B}-\mathrm{H}]^{-}$and ion abundances of these ions were used for the kinetic method process.

At first, the simple kinetic method was applied as described above (eq 5); $\ln [\mathrm{A}-\mathrm{H}]^{-} /[\mathrm{B}-\mathrm{H}]^{-}$values were plotted against the $\Delta \mathrm{G}_{\text {acid }}$ values of the reference compounds at $298 \mathrm{~K}$. These plots resulted in a straight line with a slope $1 / \mathrm{RT}_{\text {eff }}$ and intercept $-\Delta \mathrm{G}_{\mathrm{acid}} / \mathrm{RT}_{\text {eff }}$. The $\Delta \mathrm{G}_{\text {acid }}$ values of deoxyribonucleosides were calcu-

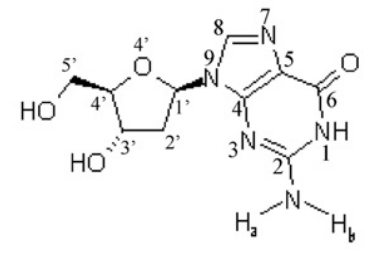

2'deoxyguanosine

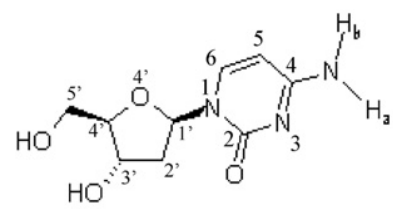

2'deoxycytidine

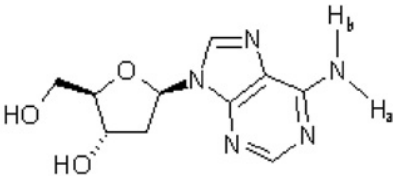

2'deoxyadenosine

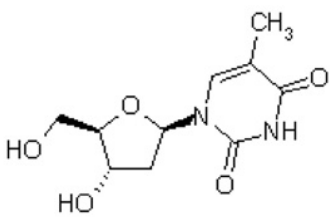

2'deoxythymidine
Scheme 1. Structures of deoxyribonucleosides with each atom numbered typically for purine and pyrimidine. 


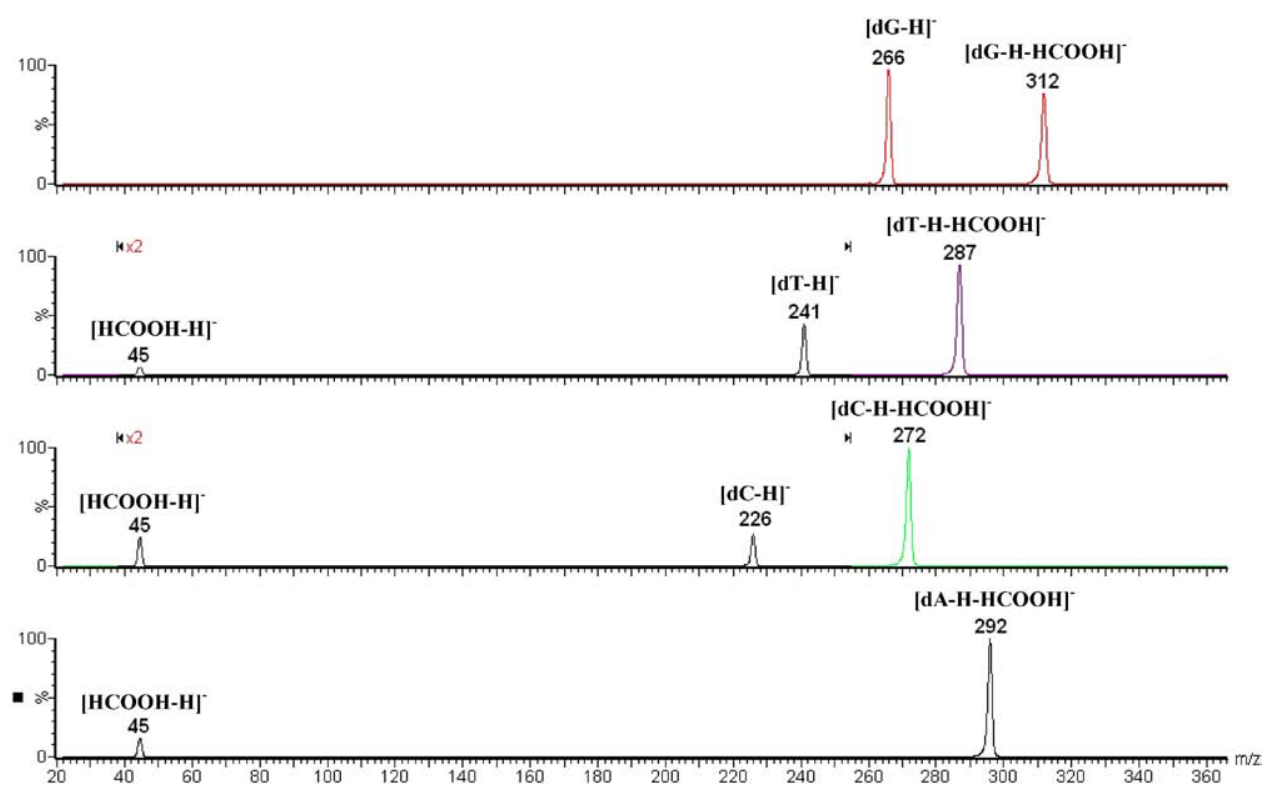

Figure 1. CID spectra of proton bound deprotonated deoxyribonucleosides and formate anion at constant collision activation conditions.

lated from the slopes and intercepts (data presented in Table S1 of Supplementary Material, which can be found in the electronic version of this article). Among the deoxyribonucleosides, $\mathrm{dA}$ has the highest $\Delta \mathrm{G}_{\text {acid }}$ and $\mathrm{dG}$ the lowest. However, it was noticed that upon collision energy increase there was a small but significant change in the $\Delta \mathrm{G}_{\text {acid }}$ values ranging from 1 to 3 $\mathrm{kJ} / \mathrm{mol}$ (shown in Table S1 of Supplementary Material ), which could be due to the entropy effects. Thus, we applied the extended kinetic method suggested by Armentrout [30] to determine enthalpy differences.

The plots of $\ln \left\{\left[\mathrm{A}-\mathrm{H}^{-}\right] /\left[\mathrm{B}-\mathrm{H}^{-}\right]\right\}$obtained at each specific collision energy against $\left[\Delta \mathrm{H}_{\text {acid }}(B)-\Delta \mathrm{H}_{\text {acid }}\left(\mathrm{B}_{\text {avg }}\right)\right]$ gave a straight line with slope $\left[1 / \mathrm{RT}_{\text {eff }}\right]$ and intercept $\left\{-\left[\Delta G^{\text {app }}(\mathrm{A})-\Delta \mathrm{H}_{\text {acid }}(\mathrm{B})_{\text {avg }}\right] / \mathrm{RT}_{\text {eff }}\right\}$. Such plots were attained at the four different collision energies; typical plots of dG are shown in Figure 2 (the plots of dA, dC, and dT are shown in Supplementary Material). Using the resultant slopes and intercepts, $T_{\text {eff }}$ and $\Delta \mathrm{G}_{\text {acid }}{ }^{\text {app }}$ values

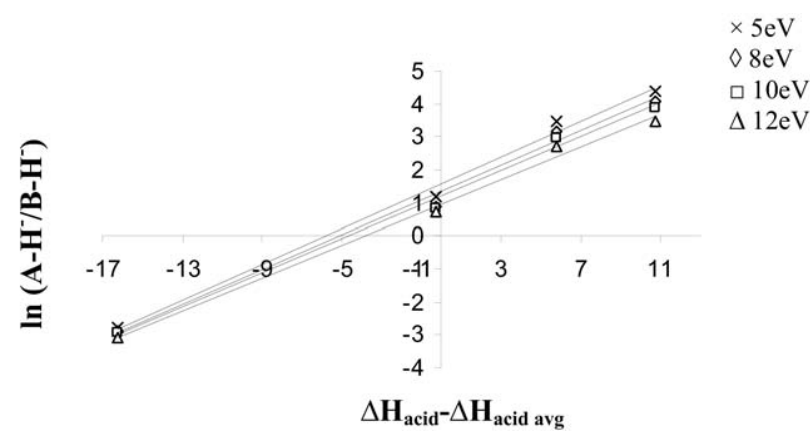

Figure 2. Plots of the measured product ion abundance ratio, $\ln \left(\mathrm{A}-\mathrm{H}^{-} / \mathrm{B}-\mathrm{H}^{-}\right)$for $2^{\prime}$-deoxyguanosine versus $\Delta \mathrm{H}_{\text {acid }}-$ $\Delta \mathrm{H}_{\text {acid avg }}(\mathrm{kJ} / \mathrm{mol})$ of reference compounds at $5,8,10$, and 12 $\mathrm{eV}$ collision energy. were obtained as tabulated in Table 2 . To obtain the entropy term, the negatives of intercept obtained at different collision energies were plotted against the corresponding slopes (the plot of dG shown in Figure 3 as an example, and plots of $\mathrm{dA}, \mathrm{dC}$, and $\mathrm{dT}$ are shown in Supplementary Material). From this plot, the value of $\left[\Delta \mathrm{H}_{\text {acid }}(\mathrm{A})-\Delta \mathrm{H}_{\text {acid }}(\mathrm{B})_{\mathrm{avg}}\right]$ and [$\left.\Delta\left(\Delta \mathrm{S}_{\text {acid }}\right) / \mathrm{R}\right]$ were then extracted from the slope and the intercept, respectively.

The $\Delta \mathrm{G}_{\text {acid }}$ app and $\mathrm{T}_{\text {eff }}$ values increased as a function of collision energy (Table 2), signifying increased energy deposition with an increase in the collision energy. The $\Delta \mathrm{S}_{\text {acid }}$ value of the analyte was calculated from the average value of $\Delta \mathrm{S}_{\text {acid }}$ for the reference compounds at $298 \mathrm{~K}$ and the $\Delta\left(\Delta \mathrm{S}_{\text {acid }}\right)$ value obtained from the intercept of the plot (Table 2). These $\Delta S_{\text {acid }}$ values were used to calculate the $\Delta \mathrm{G}_{\text {acid }}$ of the deoxyribonucleosides at $298 \mathrm{~K}$, and are summarized in Table 2. The order of $\Delta \mathrm{H}_{\text {acid }}$ values of deoxyribonucleosides determined from the extended kinetic method is found to be similar to the order of $\Delta G_{\text {acid }}$ values, mainly because of closer entropic contributions (Table 2) of deoxyribonucleosides.

The determined $\Delta \mathrm{H}_{\text {acid }}$ values of the deoxyribonucleosides are in the order of $\mathrm{dA}>\mathrm{dC}>\mathrm{dT}>\mathrm{dG}$. Though the deoxyribonucleosides $\mathrm{dA}$ and $\mathrm{dG}$ come under the purine base containing deoxyribonucleosides, a large difference exists between their $\Delta \mathrm{H}_{\text {acid }}$ values. The measured $\Delta \mathrm{H}_{\text {acid }}$ values for $\mathrm{dA}$ and $\mathrm{dG}$ are in good agreement with their known solution phase acidity constant values in the literature. The deoxyribonucleosides $\mathrm{dA}$ and $\mathrm{dG}$ were well studied in the solution phase because of their self-association properties (stacking interactions) [33-35]. The acidity constant values obtained for $\mathrm{dG}$ and $\mathrm{dA}$ from potentiometric $\mathrm{pH}$ titrations in dilute aqueous solutions [35] were 2.30 and 
Table 2. The $\Delta \mathrm{H}, \Delta \mathrm{S}$, and $\Delta \mathrm{G}$ values for deoxyribonucleosides obtained by the extended kinetic method*

\begin{tabular}{|c|c|c|c|c|c|c|c|}
\hline \multirow[b]{2}{*}{ Comp. } & \multicolumn{4}{|c|}{$\Delta \mathrm{G}^{\mathrm{app}}(\mathrm{kJ} / \mathrm{mol})$} & \multirow[b]{2}{*}{$\Delta \mathrm{H}_{\text {acid }}(\mathrm{kJ} / \mathrm{mol})$} & \multirow{2}{*}{$\begin{array}{c}\Delta \mathrm{S} \\
(\mathrm{J} / \mathrm{mol} / \mathrm{k})\end{array}$} & \multirow{2}{*}{$\begin{array}{l}\Delta \mathrm{G}_{\text {acid }}=\Delta \mathrm{H}- \\
\mathrm{T} \Delta \mathrm{S}(\mathrm{kJ} / \mathrm{mol})\end{array}$} \\
\hline & $5 \mathrm{eV}$ & $8 \mathrm{eV}$ & $10 \mathrm{eV}$ & $12 \mathrm{eV}$ & & & \\
\hline dG & $\begin{array}{c}1387.4 \pm 0.1 \\
{[465]}\end{array}$ & $\begin{array}{c}1388 \pm 0.1 \\
{[477]}\end{array}$ & $\begin{array}{c}1388.6 \pm 0.1 \\
{[489]}\end{array}$ & $\begin{array}{c}1389.2 \pm 0.1 \\
{[507]}\end{array}$ & $1367 \pm 2.2$ & $53.7 \pm 3.8$ & $\begin{array}{c}\text { at } 298 \mathrm{~K} \\
1351 \pm 1.0(2.4)\end{array}$ \\
\hline $\mathrm{dA}$ & $\begin{array}{c}1462 \pm 0.1 \\
{[662]}\end{array}$ & $\begin{array}{c}1464.3 \pm 0.1 \\
{[702]}\end{array}$ & $\begin{array}{c}1466 \pm 0.1 \\
{[746]}\end{array}$ & $\begin{array}{c}1467.3 \pm 0.2 \\
{[772]}\end{array}$ & $1430 \pm 1.5(3.7)$ & $52.5 \pm 2.7$ & $1415 \pm 0.7(1.7)$ \\
\hline $\mathrm{dC}$ & $\begin{array}{c}1455.8 \pm 0.2 \\
{[530.5]}\end{array}$ & $\begin{array}{c}1457.2 \pm 0.1 \\
{[545]}\end{array}$ & $\begin{array}{c}1458.3 \pm 0.0 .1 \\
{[571]}\end{array}$ & $\begin{array}{c}1459.6 \pm 0.2 \\
{[601]}\end{array}$ & $1409 \pm 2.5(6.0)$ & $47.0 \pm 4.4$ & $1394.6 \pm 1.2(2.9)$ \\
\hline $\mathrm{dT}$ & $\begin{array}{c}1428.6 \pm 0.0 .7 \\
{[563]}\end{array}$ & $\begin{array}{c}1430.4 \pm 0.1 .0 \\
{[594]}\end{array}$ & $\begin{array}{c}1431.4 \pm 0.0 .9 \\
{[611]}\end{array}$ & $\begin{array}{c}1432.8 \pm 1.0 \\
{[640]}\end{array}$ & $1399 \pm 1.7(4.0)$ & $42.8 \pm 3.4$ & $1386 \pm 1.0(2.4)$ \\
\hline
\end{tabular}

*The value in the [ ] indicates $\mathrm{T}_{\text {eff }}$ values in $\mathrm{K} . \pm$ Standard deviation from the triplicate data. The value in parentheses ( ) indicates uncertainties at $95 \%$ confidence limit.

$3.74\left(25^{\circ} \mathrm{C} ; \mathrm{I}=0.1 \mathrm{M}, \mathrm{NaNO}_{3}\right)$, respectively. Higher the acidity constant value lower will be the acidity, and thus $\mathrm{dG}$ is more acidic than $\mathrm{dA}$ in aqueous solutions, and this correlates with the gas-phase results in the present study. The large difference in the measured $\Delta \mathrm{H}_{\text {acid }}$ values of $\mathrm{dA}$ and $\mathrm{dG}$ could be due to structural differences in the nucleobases (adenine and guanine), because in both cases the bases are linked to the same sugar moiety at N-9 of the nucleobase through the glycosidic bond. The adenine and guanine have similar core structures but from the chemical point of view, these two bases differ significantly. Adenine has the primary amine group at C-6, whereas the guanine, in addition to the primary amine group at $\mathrm{C}-2$, has an extra acidic proton at the $\mathrm{N}-1$ that is in conjugation with the keto-group at C-6. These addition structural features in $\mathrm{dG}$ might be responsible for its least $\Delta \mathrm{H}_{\text {acid }}$ value among the studied deoxyribonucleosides. Further, theoretical calculations were carried out for better understanding the experimentally obtained $\Delta \mathrm{H}_{\text {acid }}$ order for deoxyribonucleosides.

\section{Computational Results}

Density functional theory (DFT) methods were used to study the $\Delta \mathrm{H}_{\text {acid }}$ values of the deoxyribonucleosides. Topol et al. [36] calculated the $\Delta \mathrm{H}_{\text {acid }}$ values of glycine
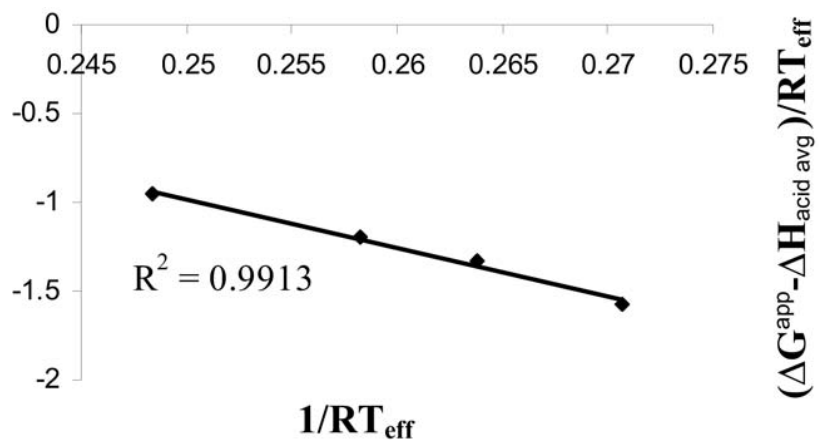

Figure 3. Plot of $\left\{\left(\Delta G^{\text {app }}(\mathbf{d G})-\Delta \mathrm{H}_{\text {acid avg }}\right) / \mathrm{RT}_{\text {eff }}\right\}$ versus $1 / \mathrm{RT}_{\text {eff }}$ used for $2^{\prime}$-deoxyguanosine to determine $\Delta \mathrm{H}_{\text {acid }}$ from the slope and $\Delta \Delta \mathrm{S}_{\text {acid }}$ from the intercept. and alanine using a variety of high-level theoretical methods. There was a good agreement of high level calculations results with the measured values; thus, they concluded the DFT methods represent the best tools for obtaining $\Delta \mathrm{H}_{\text {acid }}$ values for medium to large sized molecular systems. Ground state geometries for the studied deoxyribonucleosides were taken from the earlier study [18], in which C3'-endo/anticonformer for $\mathrm{dC}$ and $\mathrm{C} 2{ }^{\prime}$-endo/anti for the remaining deoxyribonucleosides were considered. The reoptimized geometries of the molecules obtained at the B3LYP/6-311G** level of theory were in good agreement with the earlier reported data [18]. Single point energy calculations at B3LYP / 6-311 $+\mathrm{G}^{* *}$ were then performed at the B3LYP/ $6-311 G^{* *}$ geometries to obtain the final total electronic energies. The total electronic energies at the B3LYP/6$311+\mathrm{G}^{* *}$ geometries were converted to enthalpies at 298 $\mathrm{K}$ using unscaled vibrational frequencies at the B3LYP/ $6-311 G^{* *}$ geometries. The calculated values of electronic energies, thermal corrections, and enthalpies at $298 \mathrm{~K}$ are given in Table 3. Optimized geometries of the lowestenergy neutrals and most stable deprotonated forms of deoxyribonucleosides are provided in Figure 4.

In the case of deoxyribonucleosides, the most acidic site of the free bases was substituted with sugar moiety. Therefore, the most acidic site in the deoxyribonucleosides can be presumed to be the second most acidic proton of the corresponding free nucleobase. Kenttamaa et al. $[19,37]$ calculated the $\Delta \mathrm{H}_{\text {acid }}$ values of free nucleobases at all sites, and the order of $\Delta \mathrm{H}_{\text {acid }}$ value for second most acidic proton was $9 \mathrm{H}$-adenine $\left(\mathrm{N} 4-\mathrm{H}_{\mathrm{b}}\right)>$ keto cytosine $\left(\mathrm{N} 4-\mathrm{H}_{\mathrm{b}}\right)>$ thymine $(\mathrm{N} 3-\mathrm{H})>9 \mathrm{H}-$ ketoguanine $\left(\mathrm{N} 2-\mathrm{H}_{\mathrm{b}}\right)$. In the present study, we obtain the $\Delta \mathrm{H}_{\text {acid }}$ of deoxyribonucleosides (at the most acidic site) in the order of $\mathrm{dA}\left(\mathrm{C}^{\prime}-\mathrm{OH}\right)>\mathrm{dC}\left(\mathrm{C} 4-\mathrm{N} 4-\mathrm{H}_{\mathrm{b}}\right)>\mathrm{dT}$ $(\mathrm{N} 3-\mathrm{H})>\mathrm{dG}\left(\mathrm{C} 2-\mathrm{N} 2-\mathrm{H}_{\mathrm{b}}\right)$. The most acidic site in the deoxyribonucleosides is indeed the second most acidic site in the corresponding free nucleobases (except dA). The acidity order of the deoxyribonucleosides matches that of the free bases (at second most acidic site); hence introduction of a sugar moiety to the nucleobase does not change the acidity 
Table 3. Calculated total electronic energies, zero-point energies, thermal corrections, and enthalpies at $298 \mathrm{~K}$ and gas phase acidities $\left(\Delta \mathrm{H}_{\text {acid }}\right)$ of deoxyribonucleosides and their deprotonated forms (energies in hartrees)

\begin{tabular}{|c|c|c|c|c|c|}
\hline & $E_{\text {tot }}^{a}$ & ZPVE $^{\mathrm{b}}$ & $\mathrm{H}^{\circ \mathrm{c}}$ & $\mathrm{H}^{\circ}{ }_{298}$ & $\Delta \mathrm{H}^{\circ}{ }_{298}(\mathrm{~kJ} / \mathrm{mol})$ \\
\hline $\mathrm{dC}$ & -816.178221 & 0.232779 & 0.247760 & -815.697681 & \\
\hline $\mathrm{dC}-\mathrm{H}\left(\mathrm{C} 4-\mathrm{N}-\mathrm{H}_{\mathrm{b}}\right)$ & -815.607143 & 0.218857 & 0.233358 & -815.15493 & 1409 \\
\hline $\mathrm{dC}-\mathrm{H}\left(\mathrm{C} 4-\mathrm{N}-\mathrm{H}_{\mathrm{a}}\right.$ & -815.616579 & 0.219340 & 0.233777 & -815.16346 & 1431 \\
\hline $\mathrm{dC}-\mathrm{H}\left(\mathrm{C}^{\prime}-\mathrm{OH}\right)^{\prime \prime}$ & -815.602673 & 0.217722 & 0.231819 & -815.15313 & 1436 \\
\hline $\mathrm{dC}-\mathrm{H}\left(\mathrm{C}^{\prime}-\mathrm{OH}\right)$ & -815.608141 & 0.217412 & 0.231409 & -815.15932 & 1420 \\
\hline dG & -963.837878 & 0.251063 & 0.267714 & -963.31910 & \\
\hline dG-H(N1-H) & -963.290902 & 0.237545 & 0.254791 & -962.798566 & 1373 \\
\hline $\mathrm{dG}-\mathrm{H}\left(\mathrm{C} 2-\mathrm{N}-\mathrm{H}_{\mathrm{b}}\right)$ & -963.285232 & 0.237202 & 0.253463 & -962.794566 & 1365 \\
\hline dG-H(C2-N-H $\left.{ }_{a}\right)$ & -963.293299 & 0.237656 & 0.253874 & -962.801769 & 1383 \\
\hline $\mathrm{dG}-\mathrm{H}\left(\mathrm{C}^{\prime}-\mathrm{OH}\right)$ & -963.255873 & 0.235261 & 0.251727 & -962.768885 & 1451 \\
\hline $\mathrm{dG}-\mathrm{H}\left(\mathrm{C} 5^{\prime}-\mathrm{OH}\right)$ & -963.263161 & 0.235692 & 0.251587 & -962.775881 & 1432 \\
\hline dT & -875.399654 & 0.249067 & 0.265225 & -874.885362 & \\
\hline dT-H(N3-H) & -874.840665 & 0.234475 & 0.250416 & -874.355773 & 1398 \\
\hline dT-H1 $\left(\mathrm{C}^{\prime}-\mathrm{OH}\right)$ & -874.819491 & 0.233004 & 0.248998 & -874.337072 & 1446 \\
\hline $\mathrm{dT}-\mathrm{H} 2\left(\mathrm{C5}^{\prime}-\mathrm{OH}\right)$ & -874.83418 & 0.233563 & 0.248929 & -874.351687 & 1407 \\
\hline $\mathrm{dA}$ & -888.576763 & 0.246188 & 0.261900 & -888.068675 & \\
\hline $\mathrm{dA}-\mathrm{H}\left(\mathrm{C} 6-\mathrm{N}-\mathrm{H}_{\mathrm{b}}\right)$ & -888.002181 & 0.232526 & 0.247710 & -887.521944 & 1439 \\
\hline $\mathrm{dA}-\mathrm{H}\left(\mathrm{C} 6-\mathrm{N}-\mathrm{H}_{\mathrm{a}}\right)$ & -888.003191 & 0.232431 & 0.247629 & -887.523131 & 1442 \\
\hline $\mathrm{dA}-\mathrm{H}\left(\mathrm{C}^{\prime}-\mathrm{OH}\right)$ & -887.993585 & 0.230578 & 0.245914 & -887.517092 & 1454 \\
\hline $\mathrm{dA}-\mathrm{H}\left(\mathrm{C} 5^{\prime}-\mathrm{OH}\right)$ & -888.004825 & 0.231030 & 0.245794 & -887.528001 & 1426 \\
\hline
\end{tabular}

a Single point energy calculation on at B3LYP/6-311+G(d,p) and optimized geometries at B3LYP/6-311G(d,p) [B3LYP/6-311+G(d,p)//B3LYP/6-311G(d,p)]. bero point vibrational energy at B3LYP/6-311G(d,p).

${ }^{\mathrm{c} T h e r m a l}$ correction at B3LYP/6-311G(d,p).

order. Thus, the deprotonation features of deoxyribonucleosides (except $\mathrm{dA}$ ) are less changed than their corresponding bases [19, 37].
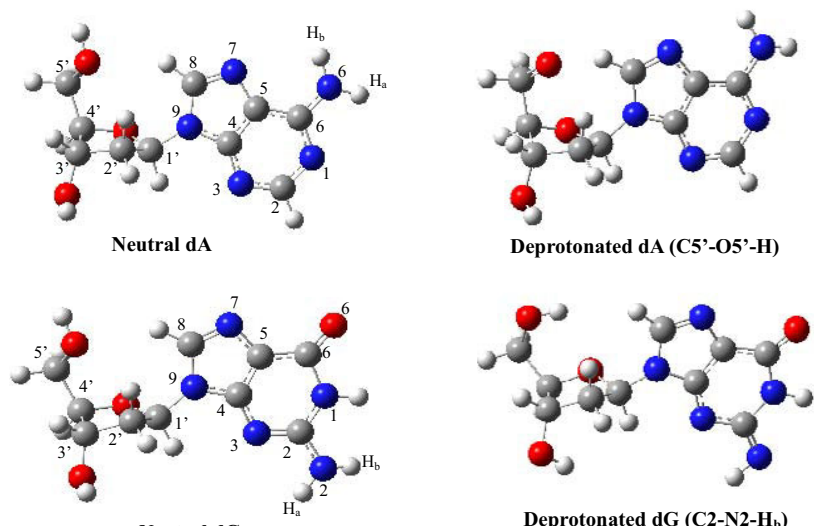

Deprotonated dG (C2-N2- $\left.\mathrm{H}_{\mathrm{b}}\right)$
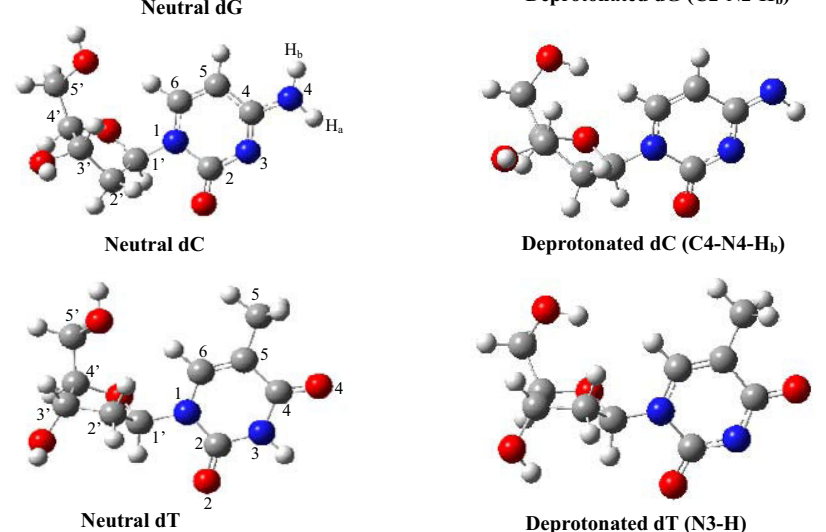

Figure 4. Geometries of neutral and most stable deprotonated forms of all the deoxyribonucleosides studied in this work.
In all nucleosides, with the exception of $\mathrm{dA}$, the most acidic proton is available on the base moiety (Table 3 ). The presence of a keto group on the base moiety accommodates negative charge and forms a stable delocalized structure. Such a kind of keto group is absent in the nucleobase of $\mathrm{dA}$, and loss of a proton from the $\mathrm{NH}_{2}$ of the nitrogenous base moiety results in a doublebond character to the $\mathrm{C} 6-\mathrm{N} 6$ bond $\left(1.29 \mathrm{~A}^{0}\right)$. This leads to loss of resonance in the purine ring, hence deprotonation from nucleobase is unfavorable in dA. Between the two possible deprotonation sites $\left(\mathrm{C}^{\prime}-\mathrm{O}^{\prime}-\mathrm{H}\right.$ and $\mathrm{C}^{\prime}-\mathrm{O}^{\prime}-\mathrm{H}$ ) of the sugar moiety, $\mathrm{C}^{\prime}-\mathrm{O}^{\prime}-\mathrm{H}$ is the most favored deprotonation site in $\mathrm{dA}$. The computational evaluation of $\Delta \mathrm{H}_{\text {acid }}$ values of deoxyribonucleosides is in good agreement with the experimental results within the deviation ranges $<5 \mathrm{~kJ}$, (Table 4 ) and found to be in the order $\mathrm{dA}>\mathrm{dC}>\mathrm{dT}>\mathrm{dG}$. Further information regarding the optimized structures of the studied deprotonated forms of all nucleosides are provided in the Supplementary Materials (Figure S7-S10).

Table 4. Experimental and theoretical gas phase acidity $\left(\Delta \mathrm{H}_{\text {acid }}\right)$ values $(\mathrm{kJ} / \mathrm{mol})$ of studied deoxyribonucleosides*

\begin{tabular}{lcc}
\hline Deoxyribonucleosides & $\begin{array}{c}\Delta \mathrm{H}_{298 \mathrm{~K}} \\
\text { (theoretical) }\end{array}$ & $\begin{array}{c}\Delta \mathrm{H} \\
\text { (experimental) }\end{array}$ \\
\hline \hline 2'-Deoxyguanosine & 1365 & $1367 \pm 2.2(5.4)$ \\
2'-Deoxythymidine & 1398 & $1399 \pm 1.7(4.0)$ \\
2'-Deoxycytidine & 1409 & $1409 \pm 2.5(6.0)$ \\
2'-Deoxyadenosine & 1426 & $1430 \pm 1.5(3.7)$ \\
\hline
\end{tabular}

* Standard deviation from the triplicate data. The value in parentheses ( ) indicates uncertainties at $95 \%$ confidence limit. 


\section{Conclusion}

Here we report $\Delta \mathrm{H}_{\text {acid }}$ values of four deoxyribonucleosides $(\mathrm{dA}, \mathrm{dC}, \mathrm{dG}$, and $\mathrm{dT})$ for the first time measured by the extended kinetic method. Proton-bound heterodimeric anions of deoxyribonucleosides and a suitable reference acid were generated under negative electrospray ionization conditions, and dissociated appropriately in the collision cell. The relative abundances of the two monomeric product anions were used to measure the $\Delta \mathrm{H}_{\text {acid }}$ values. The experiments performed at different collision energy values, and the $\Delta \mathrm{H}_{\text {acid }}$ values were obtained by applying the extended kinetic method. The $\Delta \mathrm{H}_{\text {acid }}$ values were also predicted computationally by using density functional methods at B3LYP/6$311+G^{* *} / /$ B3LYP $/ 6-311 G^{* *}$ level of theory. The calculations revealed that the deprotonation is preferred from nitrogenous base, but in the case of $\mathrm{dA}$, it is from the sugar moiety. The most favored deprotonation sites are $\mathrm{C}^{\prime}-\mathrm{OH}$ of $\mathrm{dA}, \mathrm{C} 4-\mathrm{N} 4-\mathrm{H}_{\mathrm{b}}$ of $\mathrm{dC}, \mathrm{N} 3-\mathrm{H}$ of $\mathrm{dT}$, $\mathrm{C} 2-\mathrm{N} 2-\mathrm{H}_{\mathrm{b}}$ of dG. The theoretical $\Delta \mathrm{H}_{\text {acid }}$ values are in good agreement with the acidities obtained from the experiments by applying the extended kinetic method, and they are in order of $\mathrm{dA}>\mathrm{dC}>\mathrm{dT}>\mathrm{dG}$.

\section{Acknowledgments}

The authors thank Dr. J. S. Yadav, director of the Indian Institute of Chemical Technology, for the facilities and encouragement. S. K. and C. L. D. thank the Council of Scientific and Industrial Research, New Delhi, for the senior research fellowship.

\section{Appendix A Supplementary Material}

Supplementary material associated with this article may be found in the online version at doi:10.1016/ j.jasms.2009.09.019.

\section{References}

1. Puech, F. A.; Pompon, I.; Lefebvre, G.; Gosselin, G.; Imbach, J. L. Nucleotidic Prodrugs of Anti-HIV Dideoxynucleosides. Bioorg. Med. Chem. Lett. 1992, 2, 603-606.

2. Biemann, K.; McCloskey, J. Application of Mass Spectrometry to Structure Problems. VI. Nucleosides J. Am. Chem. Soc. 1962, 84, 20052007.

3. Sakurai, T.; Matsuo, T.; Kusai, A.; Nojima, K. Collisionally Activated Decomposition Spectra of Normal Nucleosides and Nucleotides Using a Four-Sector Tandem Mass Spectrometer. Rapid Commun. Mass Spectrom. 1989, 3, 212-216.

4. Reddy, D.; Iden, C. R. Analysis of Modified Deoxynucleosides by Electrospray Ionization Mass Spectrometry. Nucleosides Nucleotides. 1993, 12, 815-826.

5. Hua, Y.; Wainhaus, S. B.; Yang, Y.; Shen, L.; Xiong, Y.; Xu, X.; Zhang, F.; Bolton, J. L.; van Breemen, R. B. Comparison of Negative and Positive Ion Electrospray Tandem Mass Spectrometry for the Liquid Chromatography Tandem Mass Spectrometry Analysis of Oxidized Deoxynucleosides. J. Am. Soc. Mass Spectrom. 2001, 12, 80-87.

6. Zhang, Q.; Wang, Y. Differentiation of 2'O- and 3'O-Methylated Ribonucleosides by Tandem Mass Spectrometry. J. Am. Soc. Mass Spectrom. 2006, 17, 1096-1099.

7. Kamel, A. K.; Munson, B. Collision-Induced Dissociation of Purine Antiviral Agents: Mechanisms of Ion Formation Using Gas-Phase Hydrogen/Deuterium Exchange and Electrospray Ionization Tandem Mass Spectrometry. Eur. J. Mass Spectrom. 2004, 10, 239-257.

8. Claereboudt, J.; Esmans, E. L.; Claeys, M. Mass Spectral Behavior of $(\mathrm{M}-\mathrm{H})^{-}$Ions of Some Pyrimidine Nucleosides. Biol. Mass.Spectrom. 1993, 22, 419-421.
9. Smith, D. L.; Schram, K. H.; McCloskey, J. A. The Negative Ion Mass Spectra of Selected Nucleosides. Biomed. Mass Spectrom. 1983, 10, 269-275.

10. Crow, F. W.; Tomer, K. B.; Gross, M. L.; McCloskey, J. A.; Bergstrom, D. E. Fast Atom Bombardment Combined with Tandem Mass Spectrometry for the Determination of Nucleosides. Anal. Biochem. 1984, 139, $243-262$.

11. Xia, F.; Xie, H.; Cao, Z. Density Functional Study of Protonation of Deoxynucleosides: Electrophilic Active Sites and Proton Affinities. Int. J. Quantum. Chem. 2008, 108, 57-65.

12. DiDonna, L.; Napoli, A.; Sindona, G.; Athanassopoulos, C. A Comprehensive Evaluation of the Kinetic Method Applied in the Determination of the Proton Affinity of the Nucleic Acid Molecules. J. Am. Soc. Mass Spectrom. 2004, 15, 1080-1086.

13. Greco, F.; Liguori, A.; Sindona, G.; Uccella, N. Gas-Phase Proton Affinity of Deoxyribonucleosides and Related Nucleobases by Fast Atom Bombardment Tandem Mass Spectrometry. J. Am. Chem. Soc. 1990, 112, 9092-9096.

14. Liguori, A.; Napoli, A.; Sindona, G. Survey of the Proton Affinities of Adenine, Cytosine, Thymine, and Uracil Dideoxyribonucleosides, Deoxyribonucleosides, and Ribonucleosides. J. Mass Spectrom. 2000, 35, 139-144.

15. Wilson, M. S.; McCloskey, J. A. Chemical Ionization Mass Spectrometry of Nucleosides. Mechanisms of Ion Formation and Estimations of Proton Affinity. J. Am. Soc. Mass Spectrom. 1975, 97, 3436-3444.

16. Liguori, A.; Napoli, A.; Sindona, G. Determination of Substituent Effects on the Proton Affinities of Natural Nucleosides by the Kinetic Method. Rapid Commun. Mass Spectrom. 1994, 8, 89-93.

17. Frisch, M. J.; Trucks, G. W.; Schlegel, H. B.; Scuseria, G. E.; Robb, M. A.; Cheeseman, J. R.; Montgomery, J. A., Jr.; Vreven, T.; Kudin, K. N.; Burant, J. C.; Millam, J. M.; Iyengar, S. S.; Tomasi, J.; Barone, V.; Mennucci, B.; Cossi, M.; Scalmani, G.; Rega, N.; Petersson, G. A.; Nakatsuji, H.; Hada, M.; Ehara, M.; Toyota, K.; Fukuda, R.; Hasegawa, J.; Ishida, M.; Nakajima, T.; Honda, Y.; Kitao, O.; Nakai, H.; Klene, M.; Li, X.; Knox, J. E.; Hratchian, H. P.; Cross, J. B.; Adamo, C.; Jaramillo, J.; Gomperts, R.; Stratmann, R. E.; Yazyev, O.; Austin, A. J.; Ammi, R.; Pomelli, C.; Ochterski, J. W.; Ayala, P. Y.; Morokuma, K.; Voth, G. A.; Salvador, P.; Dannenberg, J. J.; Zakrzewski, V. G.; Dapprich, S.; Daniels, A. D.; Strain, M. C.; Farkas, O.; Malick, D. K.; Rabuck, A. D.; Raghavachari, K.; Foresman, J. B.; Ortiz, J. V.; Cui, Q.; Baboul, A. G.; Clifford, S.; Cioslowski, J.; Stefanov, B. B.; Liu, G.; Liashenko, A.; Piskorz, P.; Komaromi, I.; Martin, R. L.; Fox, D. J.; Keith, T.; Al-Laham, M. A.; Peng, C. Y.; Nanayakkara, A.; Hallacombe, M.; Gill, P. M. W.; Johnson, B.; Chen, W.; Wong, M. W.; Gonzalez, C.; Pople, J. A. Gaussian 03, revision B. 01; Gaussian, Inc.: Wallingford CT, 2004.

18. Hocquet, A.; Leulliot, N.; Ghomi, M. Ground-State Properties of Nucleic Acid Constituents Studied by Density Functional Calculations. 3. Role of Sugar Puckering and Base Orientation on the Energetics and Geometry of 2'-Deoxyribonucleosides and Ribonucleosides. J. Phys. Chem. B 2000, 104, 4560-4568.

19. Huang, Y.; Kenttamaa, H. Theoretical Estimations of the 298 K GasPhase Acidities of the Purine-Based Nucleobases Adenine and Guanine. J. Phys. Chem. A 2004, 108, 4485-4490.

20. Drahos, L.; Vekey, K. Entropy Evaluation Using the Kinetic Method: is it Feasible? J. Mass Spectrom. 2003, 38, 1025-1042.

21. Cooks, R. G.; Patrick, J. S.; Kotiaho, T.; McLuckey, S. A. Thermochemical Determinations by the Kinetic Method. Mass Spectrom. Rev. 1994, 13, 287-339.

22. Mc Luckey, S. A.; Cameron, D.; Cooks, R. G. Proton Affinities from Dissociations of Proton-Bound Dimers. J. Am. Chem. Soc. 1981, 103, 1313-1317.

23. Ervin, K. M.; Armentrout, P. B. Systematic and Random Errors in Ion Affinities and Activation Entropies from the Extended Kinetic Method. J. Mass Spectrom. 2004, 39, 1004-1015.

24. Drahos, L.; Peltz, C.; Vekey, K. Accuracy of Enthalpy and Entropy Determination Using the Kinetic Method: Are We Approaching a Consensus? J. Mass Spectrom. 2004, 39, 1016-1024.

25. Bouchoux, G. Microcanonical Modeling of the Thermokinetic Method. J. Phys. Chem. A 2006, 110, 8259-8265.

26. Bouchoux, G.; Sablier, M.; Berruyer-Penaud, F. Obtaining Thermochemical Data by the Extended Kinetic Method. J. Mass Spectrom. 2004, 39, 986-997.

27. Wesdemiotis, C. Entropy Considerations in Kinetic Method Experiments. J. Mass Spectrom. 2004, 39, 998-1003.

28. Ervin, K. M. Microcanonical Analysis of the Kinetic Method. The Meaning of the "Apparent Entropy." J. Am. Soc. Mass Spectrom. 2002, 13, 435-452.

29. Ravi Kumar, M.; Prabhakar, S.; Nagaveni, V.; Vairamani, M. Estimation of Gas-Pphase Acidities of a Series of Dicarboxylic Acids by the Kinetic Method. Rapid Commun. Mass Spectrom. 2005, 19, 1053-1057.

30. Armentrout, P. B. Entropy Measurements and the Kinetic Method: A Statistically Meaningful Approach. J. Am. Soc. Mass Spectrom. 2000, 11, 371-379.

31. Caldwell, G. W.; Masucci, J. A.; Ikonomous, M. G. Negative Ion Chemical Ionization Mass Spectrometry-Binding of Molecules to Bromide and Iodide Anions. Org. Mass Spectrom. 1989, 24, 8-14. 
32. Linstrom, P. J.; Mallard, W. G., Eds.; NIST Chemistry Webbook, NIST Standard Reference Database Number 69, June 2005 Release; National Institute of Standards and Technology: Gaithersburg, MD (http:// webbook.nist.gov).

33. Corfu, N. A.; Sigel, H. Acid-Base Properties of Nucleosides and Nucleotides as a Function of Concentration. Eur. J. Biochem. 1991, 199, 659-669.

34. Tribolet, R.; Sigel, H. Self-Association and Protonation of Adenosine 5'Monophosphate in Comparison with its 2'- and $3^{\prime}$-Analogues and Tubercidin 5'-Monophosphate (7-deaza-AMP), Eur. J. Biochem. 1987, 163, 353-363.
35. Mucha, A.; Knobloch, B.; Jezówska-Bojczuk, M.; Kozłowski, H.; Sigel, R. K. O. Comparison of the Acid-Base Properties of Ribose and 2'-Deoxyribose Nucleotides. Chem. Eur. J. 2008, 14, 6663-6671.

36. Topol, A.; Burt, S. K.; Russo, N.; Toscano, M. Theoretical Calculations of Glycine and Alanine Gas-Phase Acidities. J. Am. Soc. Mass Spectrom. 1999, 10, 318-322.

37. Huang, Y.; Kenttamaa, H. Theoretical Estimations of the 298 K GasPhase Acidities of the Pyrimidine-Based Nucleobases Uracil, Thymine, and Cytosine. J. Phys. Chem. A 2003, 107, 4893-4897. 